Original article

\title{
New data about Early Cretaceous Ginkgoales from southwestern Europe (middle-late Albian of Spain) ${ }^{2 / 2}$
}

\author{
Luis Miguel Sender ${ }^{\mathrm{a}, \mathrm{b}, *}$, José Bienvenido Diez $^{\mathrm{c}}$, Javier Ferrer ${ }^{\mathrm{a}}$ \\ a Área de Paleontología, Facultad de Ciencias Edificio C (Geológicas), Universidad de Zaragoza, C/Pedro Cerbuna s/n., 50009 Zaragoza, Spain \\ ${ }^{\mathrm{b}}$ Department of Biological Sciences, Faculty of Science and Engineering, Chuo University, 1-13-27 Kasuga Bunkyo-ku, 1128551 Tokyo, Japan \\ ${ }^{\mathrm{c}}$ Departamento de Xeociencias Mariñas e Ordenación do Territorio, Facultade de Ciencias do Mar, Universidade de Vigo, 36310 Vigo Galicia, Spain
}

\section{A R T I C L E I N F O}

Article history:

Received 30 May 2017

Accepted 4 August 2018

Available online $\mathrm{xxx}$

\section{Keywords:}

Sphenobaiera

Taphonomy

Tidally-influenced environments

Palaeophytogeography

Palaeoclimatology

Southwestern Eurasia

\begin{abstract}
A B S T R A C T
We present in this work a leaf-type corresponding to the Ginkgoales genus Sphenobaiera recorded in deposits from the middle-upper Albian (Lower Cretaceous) of northeastern Spain. The fossil leaf shows a widely dissected lamina that forks regularly six times ending at the apex in sixty-four tiny wedge-shaped segments, which are characters similar to those in Sphenobaiera pecten from the Middle Jurassic of England. The exceptional preservation of this fossil leaf, which preserves all segments in connection with its base, in addition to taphonomical and sedimentological data, indicates a nearby location for the parent plant, which grew near the shores of a tidally-influenced fluvial environment. A palaeoenvironmental reconstruction of the sub-environments where the different types of Ginkgoales known from the Albian of northeastern Spain developed is also presented. The presence of a variety of different types of Ginkgoales in middle-upper Albian deposits from Spain represents a new contribution to the knowledge of the palaeoenvironmental conditions for this region of southwestern Eurasia during the late Early Cretaceous.
\end{abstract}

(c) 2018 Elsevier Masson SAS. All rights reserved.

\section{Introduction}

There are many morphological variations in fossil Ginkgoales leaves, ranging from simple lanceolate to dissected shapes. Among Mesozoic Ginkgoales, both genera Baiera Braun emend. Florin and Sphenobaiera Florin emend. Harris et Millington present similarities as they share dissected (deeply dissected occasionally) and wedge-shaped leaves with dichotomous venation, but Baiera should be used only if a distinct petiole (part below the lamina that is consistent in width) is present, while Sphenobaiera should be used exclusively for this kind of leaves that lack a distinct petiole (Harris et al., 1974).

Evidences concerning the presence of gingoalean leaves in the "mid" Cretaceous (Albian to Turonian) from western Eurasia within the Eurosinian province - were classically restricted to records of taxa with simple, oblanceolate-shaped lamina corresponding to the genera Eretmophyllum Thomas and Nehvizdya Hluštik - despite the last genus is considered as a synonym of the first one by many authors - from the Albian deposits of Spain (Gomez et al., 2000; Sender, 2012) and from the Cenomanian of

\footnotetext{
Corresponding editor: Borja Cascales-Miñana.

* Corresponding author.

E-mail address: Imsender@yahoo.es (L.M. Sender).
}

France (Pons et al., 1976, 1980; Nguyen Tu et al., 1999) and Czech Republic (Hluštík, 1977, 1986; Knobloch and Mai, 1999; Kvacek, 1999).

Other genera within Ginkgoales that show leaves with a dissected lamina - as Ginkgoites Seward emend. Watson, Lydon et Harrison, and Sphenobaiera - constitute a common record in the Upper Triassic to basal Lower Cretaceous continental deposits from the Eurosinian region (Zhou, 2009), except for the Albian Stage where they are absent. Nevertheless, relatively recent findings from the Iberian Peninsula changed this assertion because complete leaves of the two cited ginkgoalean genera where found in middle-upper Albian fluvial deposits in northeastern Spain (Sender et al., 2005, 2008).

In this work, a new kind of ginkgoalean leaf corresponding to the genus Sphenobaiera is described from Albian deposits in northeastern Spain, western Eurasia. This new finding gives support to previous data indicating that warm and humid environmental conditions were present in the Iberian Plate during the late Early Cretaceous.

\section{Geographical and geological settings}

The ginkgoalean leaf studied in this paper was collected in the so-called San Just-2 fossil site, close to the Utrillas village in the 
Cuencas Mineras Comarcal (Teruel Province, Aragón region, northeastern Spain; coordinates: 40 46’42.58”N, 0 ${ }^{\circ} 50^{\prime} 03.22 ’ \mathrm{~W}$ ), which is located $118 \mathrm{~km}$ south of Zaragoza city and $64 \mathrm{~km}$ north of Teruel city (Fig. 1). The stratigraphic level containing the studied fossil leaf belongs to the upper part of the Middle Member - or "Regachuelo" Member - of the Escucha Fm. (Aguilar et al., 1971; Fig. 2), a mainly continental detrital unit consisting of alternate sandstones and clays with intercalations of coal seams and sporadic marine limestones deposited in a delta-estuary system with tidal influence (Pardo and Villena, 1979; Pardo et al., 1991; Querol, 1990; Querol et al., 1992; Salas et al., 2001). The Escucha Fm. in this area overlays the marine deposits of the Villarroya de los Pinares Fm., which is Aptian in age in the Utrillas area (VillanuevaAmadoz et al., 2010); it is limited to the top by the sandy fluvial deposits of the Utrillas Fm., which is middle-late Albian in age. The stratigraphical level of the San Just-2 fossil site containing the studied Ginkgoales leaf has yielded an angiospermous palynological assemblage composed of several species corresponding to monosulcates genera (Clavatipollenites Couper, Dichastopollenites May, Hammenia Ward, Jusinghipollis Jansonius et Hills, Liliacidites Couper, Pennipollis Friis, Pedersen et Crane, Retimonocolpites Pierce emend. Juhász et Góczán, and Transitoripollis Góczán et Juhász) and also tricolpates (Phimopollenites Dettmann, Rousea Srivastava, Striatopollis Krutzsch, and Tricolpites Cookson ex Couper emend. Jarzen et Dettmann), which indicate a middle to late Albian age for the fossil site (Villanueva-Amadoz et al., 2010). The lithology of the stratigraphic interval where the fossil was found in San Just-2 locality exhibits white to light brown cross-bedded sandstones with intercalations of grey-colored claystones and siltstones (Querol et al., 1992; Pardo et al., 1991).

\section{Material and methods}

The studied fossil consists of an impression of a single leaf preserved in grey-colored siltsones. The fossil was prepared using a pneumatic hammer, small needles and soft brushes. Photographs of the fossil leaf were took using a Nikon D-90 camera with an AF-S Micro Nikkor $60 \mathrm{~mm}$ macro-lens. The specimen is stored at the Museo Paleontológico Aragonés - Fundación Conjunto Paleontológico de Teruel (Teruel city, Spain) under the designation MAP-7726.

\section{Systematic palaeobotany}

Order Ginkgoales Warburg, 1913.

Family Ginkgoaceae Engler, 1897.

Genus Sphenobaiera (Florin) emend. Harris et Millington, 1974. Sphenobaiera cf. pecten (Harris) emend. Harris et Millington, 1974.

Fig. 3

Description: Nearly complete leaf, wedge-shaped in outline, $7.4 \mathrm{~cm}$ long and $5.3 \mathrm{~cm}$ wide, presenting an acute to attenuate base without a distinct petiole (Fig. 3(A)). The length of basal region is $4.5 \mathrm{~mm}$, with lamina deeply divided into two primary segments (Fig. 3(D)) which divides in long linear-shaped segments forking six times (Fig. 3(A)) to end in two tiny and thin linear-shaped segments at the top of the leaf (Fig. 3(C)). The complete leaf would present sixty-four apical tiny wedge-shaped segments at its apex. Angle of dichotomies is about $15^{\circ}$ to $20^{\circ}$ in basal medial dichotomies and less than $5^{\circ}$ on average in the terminal ones. Maximum width of segments in medial zone of the leaf is $2 \mathrm{~mm}$; minimum width of segments, corresponding to the apical zone, is $0.8 \mathrm{~mm}$. The maximum width of segments between dichotomies is located in the medial zone ( $1.8 \mathrm{~mm}$ wide), becoming narrower towards both the base and the apex of the leaf (Fig. 3(A)). Veins are straight and marked, running parallel to the margins. Apparently, a single basal vein dichotomizes from the base to the apex of the lamina with four to five veins per segment in the median area of the leaf (Fig. 3(B)). Vein density in the widest part of segments is 3 veins per $\mathrm{mm}$. The number of veins decreases in the thin linearshaped segments at the top of the leaf up to two veins, which enter each apical segment ending in the distal margin.
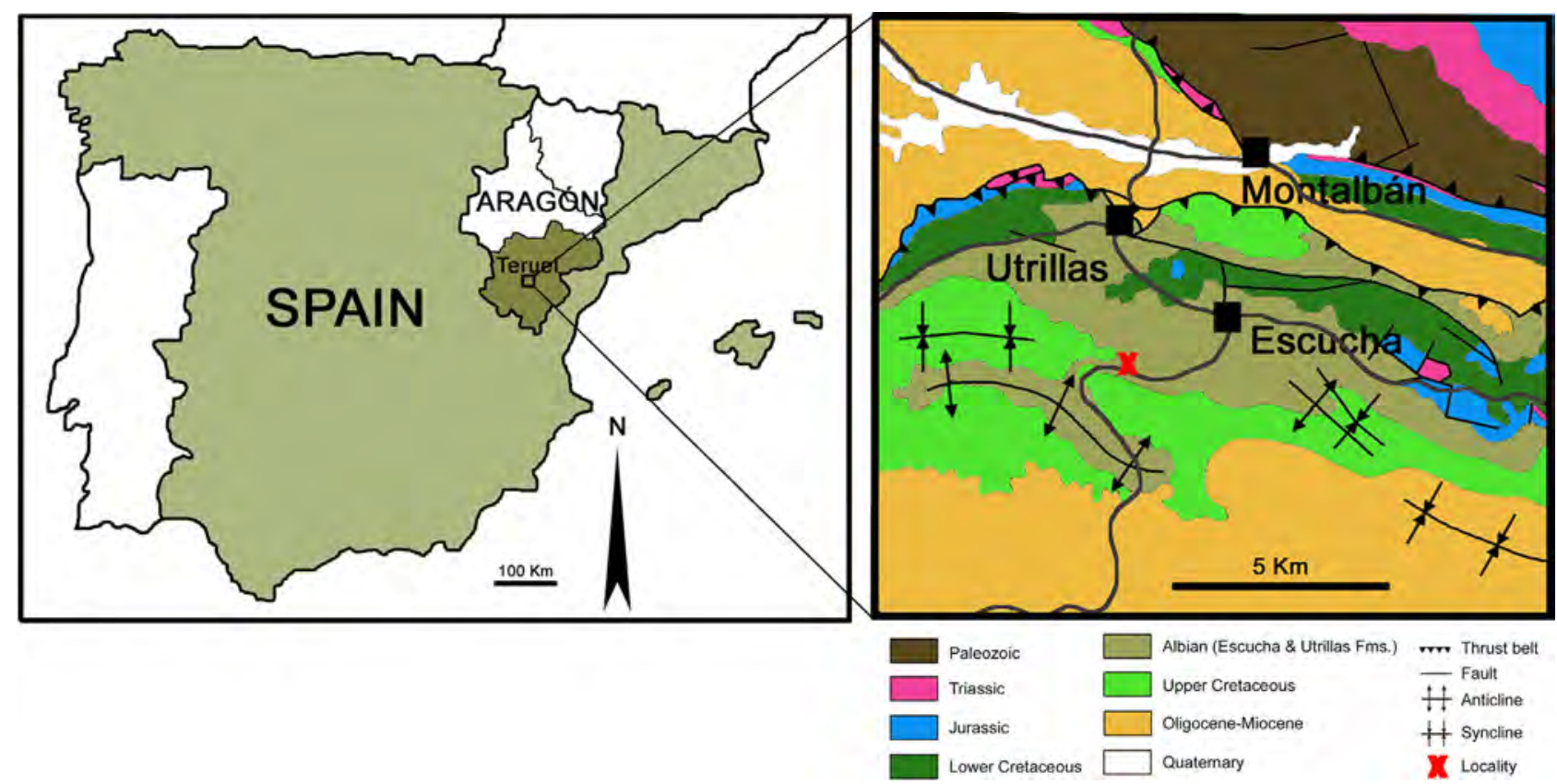

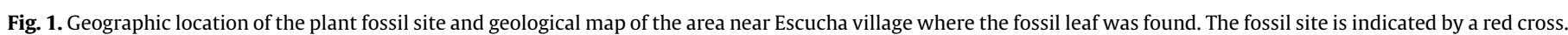

Please cite this article in press as: Sender, L.M., et al., New data about Early Cretaceous Ginkgoales from southwestern Europe (middlelate Albian of Spain). Geobios (2018), https://doi.org/10.1016/j.geobios.2018.08.011 


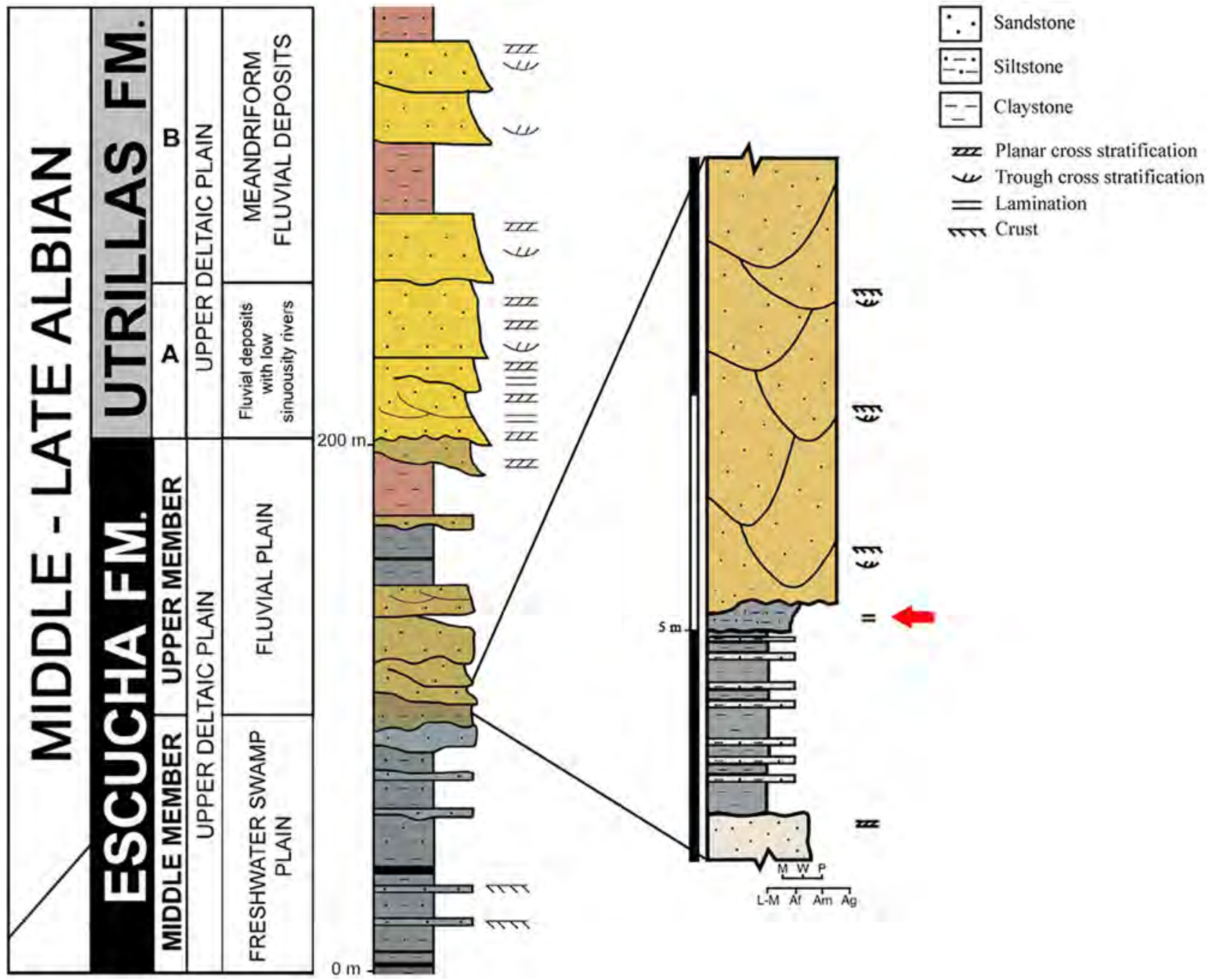

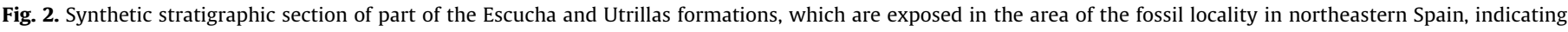

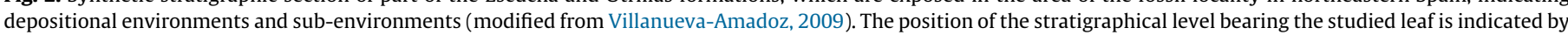
a red arrow.

\section{Discussion}

\subsection{Taxonomical remarks}

The genus Sphenobaiera occurs in Mesozoic deposits worldwide (Zhou, 2009; Bauer et al., 2013). Cretaceous records of this taxon in Laurasia have been found:

- in Lower Cretaceous deposits from south Prymorye (Krassilov, 1967), Bureja (Krassilov, 1972) and Aldan basins (Samylina, 1956, 1963, 1967);

- in Albian deposits of northern Siberia (Spicer and Herman, 2001; Herman and Spicer, 2010), all of them in Russia;

- in the Lower Cretaceous of northern China (Guo, 1990) and Mongolia (Sun et al., 2003);

- in Albian to Cenomanian rocks from Alaska (Spicer and Herman, 2001);

- in Lower Cretaceous deposits from the Bowser Basin in Canada (MacLeod and Hills, 1991) and the Black Hills from western USA (Cahoon, 1960);

- in Barremian to Aptian deposits from Greenland (Seward, 1926; Lydon et al., 2003) and Svalbard (Pott et al., 2016).
The Cretaceous species of this genus exhibit a common morphological pattern that consists of deeply dissected leaves lacking a distinct petiole with a triangular and wedge-shaped lamina, which present from two to five primary segments that fork at least once, showing dichotomous venation (Florin, 1936; Harris et al., 1974).

The leaf described here from the Albian of Spain fits well with the diagnosis of this genus, but some singular characteristics as the number of dichotomies of the thin segments and the number of apical segments morphologically distinguish it from all Cretaceous species known to date. It differs mainly from genus Baiera in the absence of a true petiole and especially in the number of veins per lobe: typically between 2 to 4 in Baiera and 4 to 6 in Sphenobaiera. (Florin, 1936).

Unfortunately, the studied leaf does not preserve cuticular remains, which could indicate a possible relation with a known species. The external morphology of the studied leaf resembles those observed in several Sphenobaiera species from Upper Triassic to Lower Cretaceous deposits around the world (Table 1). Nevertheless, characters as the dissected morphology of the lamina, the number of successive divisions of the segments, the 

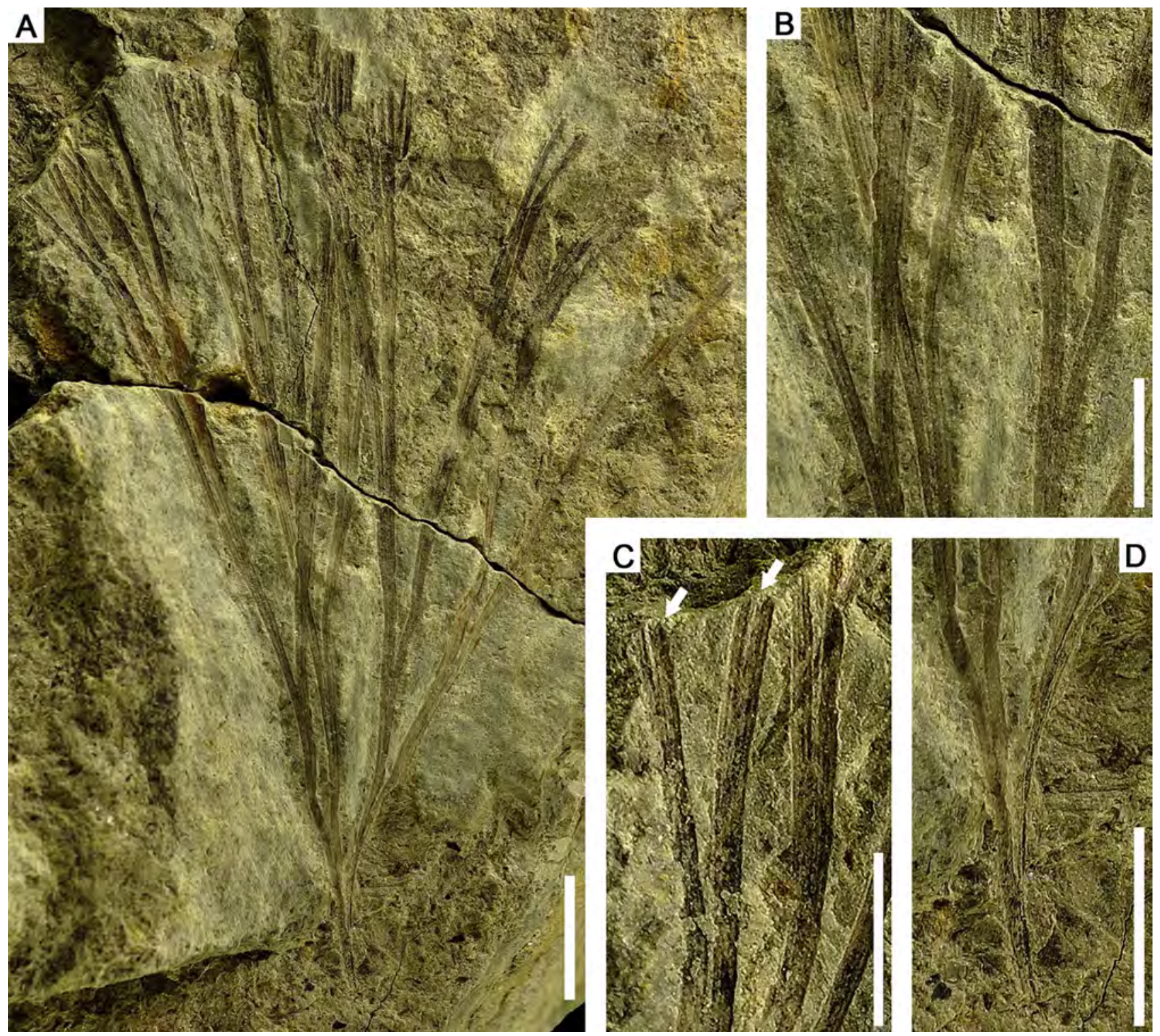

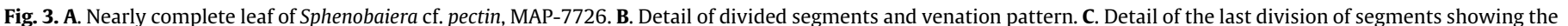

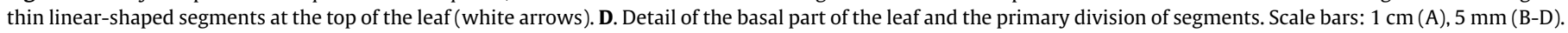

number of dichotomous veins present on them, and the angle between of dichotomies fit with those observed in Sphenobaiera pecten Harris from the Middle Jurassic deposits of Yorkshire, England (Harris et al., 1974). On the other hand, terminal segments in our leaf are both shorter and wider than those from the leaves of the English Jurassic deposits. In addition, two veins enter these terminal segments in the Spanish specimen, which differs from the single medial vein ending at the tip of the ultimate segments in the leaves from the Yorkshire locality. The main difference between the studied leaf and leaves of Sphenobaiera pecten consists on the vein density, which is three times larger in the present specimen (i.e., 3 vs. 1 vein per $\mathrm{mm}$ ). This fact is due to the narrow segments

Table 1

Comparison between the studied leaf and other similar-shaped leaves assigned to Sphenobaiera species.

\begin{tabular}{|c|c|c|c|c|c|c|c|}
\hline Species & Lamina & $\begin{array}{l}\text { Division } \\
\text { times }\end{array}$ & $\begin{array}{l}\text { Shape of } \\
\text { medial segments }\end{array}$ & $\begin{array}{l}\text { Maximum } \\
\text { width of } \\
\text { segments }\end{array}$ & $\begin{array}{l}\text { Shape } \\
\text { of last } \\
\text { segments }\end{array}$ & $\begin{array}{l}\text { Number } \\
\text { of veins }\end{array}$ & $\begin{array}{l}\text { Vein density } \\
\text { (per } \mathrm{mm} \text { ) }\end{array}$ \\
\hline Sphenobaiera schenkii (Feistmantel) Florin & Wedge-shaped & 4 & Linear-shaped & $3 \mathrm{~mm}$ & Narrow linear & $2-5$ & 2 \\
\hline $\begin{array}{l}\text { Sphenobaiera pecten (Harris) emend. Harris et } \\
\text { Millington }\end{array}$ & Wedge-shaped & 6 & Linear-shaped & $3 \mathrm{~mm}$ & Thin linear & $1-4$ & 1 \\
\hline $\begin{array}{l}\text { Sphenobaiera longifolia Pomel (Florin) emend. } \\
\text { Harris et Millington }\end{array}$ & Wedge-shaped & 4 & Linear-shaped & $6 \mathrm{~mm}$ & Narrow linear & $4-11$ & 2 \\
\hline Sphenobaiera ophyoglossum Harris et Millington & Narrowly wedge-shaped & 3 at least & Linear-shaped & $8 \mathrm{~mm}$ & Narrow linear & $5-19$ & 2 \\
\hline Sphenobaiera ikorfatensis (Seward) Florin & Narrowly wedge-shaped & 2 & Strap-shaped & $8-10 \mathrm{~mm}$ & Rounded & $10-15$ & 1 \\
\hline Sphenobaiera spetsbergensis (Nathorst) Florin & Narrowly wedge-shaped & 2 & Linear-shaped & $1 \mathrm{~mm}$ & Rounded & Numerous & - \\
\hline Sphenobaiera cf. pecten (this paper) & Wedge-shaped & 6 & Linear-shaped & $1.8 \mathrm{~mm}$ & Thin linear & $2-5$ & 3 \\
\hline
\end{tabular}

Please cite this article in press as: Sender, L.M., et al., New data about Early Cretaceous Ginkgoales from southwestern Europe (middlelate Albian of Spain). Geobios (2018), https://doi.org/10.1016/j.geobios.2018.08.011 


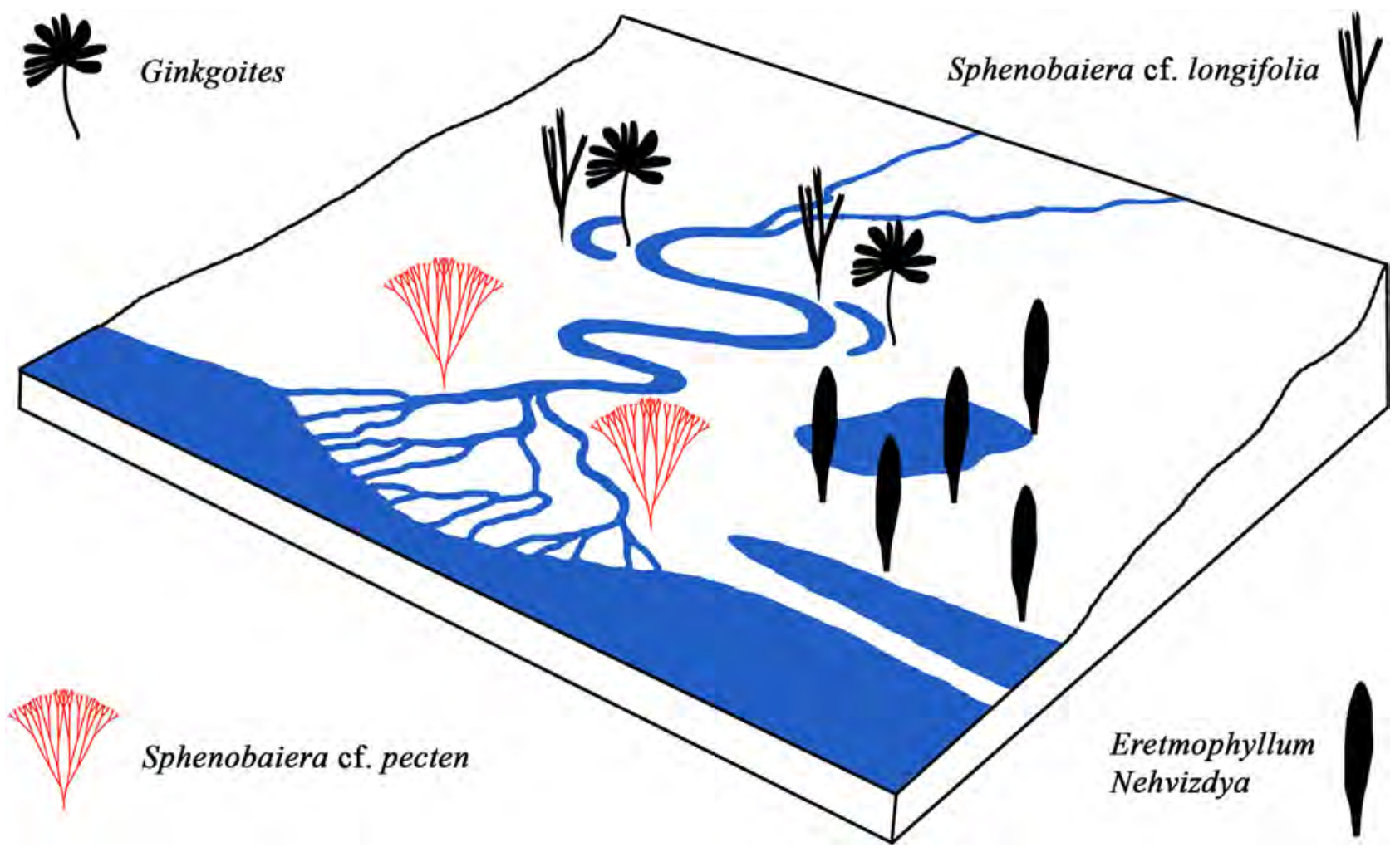

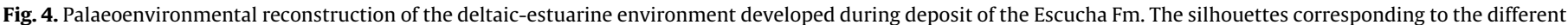
genera and species of Ginkgoales recorded in this geological formation are associated with the closest sub-environments where they grew (see Section 5.2).

on the studied leaf, which are almost half the size of those in Sphenobaiera pecten.

\subsection{Palaeoenvironmental and palaeophytogeographical implications}

Some other Ginkgoalean leaves have been found previously in the middle to upper Albian deposits of northeastern Spain: leaves of Eretmophyllum andegavense Pons, Boureau et Broutin from the Escucha, Utrillas and Portalrubio localities (Sender, 2012) and Nehvizdya penalveri Gomez from Rubielos de Mora locality, both taxa being recorded in deposits of the Middle Member of the Escucha Fm., and Ginkgoites cf. pluripartita and Sphenobaiera cf. longifolia from Alcaine locality deposits corresponding to the Upper Member of the same geological formation (Sender et al., 2008). The data provided by the preservation of fossil remains and the sedimentological features of the deposits containing them make it possible to relate the plants bearing these leaves to the nearby areas of different depositional sub-environments within the deltaic-estuarine environment that was present in this area during Albian times (Fig. 4).

A great amount of complete Ginkgoalean leaves corresponding to Eretmophyllum andegavense and Nehvizdya penalveri species were found as concentrations in laminated claystones deposited in both brackish and freshwater swamp sub-environments. This great amount of leaves and their good preservation - with both apex and base intact - would indicate a minimum transportation from the areas where these plants grew. On the other hand, leaves of Ginkgoites cf. pluripartita and Sphenobaiera cf. longifolia preserve petioles in connection with laminae and segments of leaves with their apex without any biostratinomical evidences of alteration due to transportation. Both facts constitute clear evidences indicating that the parent plants of these leaves grew in the close vicinity of oxbow lakes and inundated areas of fluvial plains where they were buried (Querol et al., 1992; Sender et al., 2008; Sender, 2012; Fig. 4; Table 2). The exquisite preservation of the leaf Sphenobaiera cf. pecten from San Just-2 locality described here preserving all segments in connection without evidences of erosive transportation by water - would also indicate that its parent plant grew in the close vicinity of a tidally-influenced fluvial environment where the leaf was buried.

Based on the observed stratigraphic sequences and sedimentary structures - as "herring-bone" lamination and typical rhythmites with cross-lamination containing mud drapes and re-activation surfaces -, the sedimentary interpretation relates these deposits with highly tidally-influenced fluvial environments close to the sea, departing from deposits containing the other mentioned Ginkgoalean leaves that show depositional conditions

Table 2

Occurrence of Ginkgoalean remains in localities from the Albian deposits of northeastern Spain and their related sedimentary depositional environments.

\begin{tabular}{|c|c|c|c|c|}
\hline Species & Geological unit & Localities in Spain & Depositional environments & References \\
\hline Nehvizdya penalveri & Middle Member of Escucha Fm. & Rubielos de Mora & Brackish and freshwater swamps & Gomez et al. (2000) \\
\hline Eretmophyllum andegavense & Middle Member of Escucha Fm. & Escucha, Utrillas, Portalrubio & Brackish and freshwater swamps & Sender (2012) \\
\hline Ginkgoites cf. pluripartita & Upper Member of Escucha Fm. & Alcaine & Oxbow lake and fluvial plain & Sender et al. (2008) \\
\hline Sphenobaiera cf. longifolia & Upper Member of Escucha Fm. & Alcaine & Oxbow lake and fluvial plain & Sender et al. (2008) \\
\hline Sphenobaiera cf. pecten & Middle Member of Escucha Fm. & Utrillas & Tidally-influenced fluvial plain & This paper \\
\hline
\end{tabular}


with a minor tidal influence (Querol et al., 1992; VillanuevaAmadoz et al., 2010; Sender, 2012).

Until the beginning of the 21th century, the evidence showed that both genera Ginkgoites and Sphenobaiera had disappeared from western Eurasia during the Early Cretaceous, being restricted to the Siberian-Canadian province since the late Aptian or early Albian (Vakhrameyeev, 1991; Pott et al., 2016). Nevertheless, evidences confirming the presence of these ginkgoalean genera have been detected in middle-upper Albian deposits of the Iberian Plate, within the southwestern part of the EuroSinian province (Sender et al., 2008; this study). The data concerning the presence of the two ginkgoalean genera in this area, in addition to the presence of "out of place" taxa corresponding to some Pteridophytes (Sender et al., 2005), Gymnosperms (Sender et al., 2008) and angiosperms (Sender et al., 2016) genera, could evidence the presence of a transitional zone between the warm-subtropical belt and temperate belt in the Northern Hemisphere, which would be located in the area corresponding to the islands that constituted the Iberian Peninsula during the Albian. Nevertheless, it could also indicate that these islands may have been a southern relict refuge for these plants during middle-late Albian times, whereas they had climatic and environmental conditions similar to those of boreal regions such as the Sibero-Canadian province (Vakhrameyeev, 1991) during the late Early Cretaceous.

\section{Conclusions}

A new record of fossil leaf assigned to the genus Sphenobaiera from the middle-upper Albian deposits of northeastern Spain share some characters with Sphenobaiera pecten from the Middle Jurassic of England. Taphonomical and sedimentological data concerning preservational features of the leaf indicates that its parent plant grew close to a tidally-influenced fluvial environment. In addition to the distribution of other ginkgoaleans found within different middle-upper Albian sedimentary environments from northeastern Spain, this new record of this unexpected taxa would indicate special palaeoenvironmental conditions for this region of southwestern Eurasia during this time interval.

\section{Acknowledgements}

The authors thank the two reviewers, Alexei Herman and Mihai Popa, as well as the corresponding editor Borja Cascales-Miñana whose useful comments have improved this manuscript. We also thank Antonio Sender and students of Mining Engineering and Marine Sciences from University of Vigo for their support during the fieldworks. We thank the "Dirección General de Patrimonio Cultural" of Aragón region Government for permissions and grants to conduct fieldworks. This work is a contribution to project CGL2015-69805-P of the "Ministerio de Ciencia e Innovación", and project CGL2013-41295-P of the "Ministerio de Economía y Competitividad" of the Spanish Government. JBD was also supported by project GRC2015/020 of the "Consellería de Cultura, Educación y Ordenación Universitaria" of the Galician Government.

\section{References}

Aguilar, M.J., Ramírez del Pozo, J., Oriol Riba, A., 1971. Algunas precisiones sobre la sedimentación y la paleoecología del Cretácico Inferior en la zona de UtrillasVillaroya de los Pinares (Teruel). Estudios Geológicos 27, 497-512.

Bauer, K., Kustatscher, E., Krings, M., 2013. The ginkgophytes from the German Kupferschiefer (Permian), with considerations on the taxonomic history and use of Baiera and Sphenobaiera. Bulletin of Geosciences 88, 539-556.

Cahoon, E.J., 1960. Sphenobaiera ikorfatensis f. papillata from the Lakota formation of the Black Hills. Bulletin of the Torrey Botanical Club 87, 247-257.
Florin, R., 1936. Die fossilen Ginkgophyten von Franz-Joseph-Landnebst Erörterungenüber vermeintliche Cordaitales Mesozoischen Alters: I Spezieller Teil. Palaeontographica B 81, 71-173.

Gomez, B., Martín-Closas, C., Barale, G., Thévenard, F., 2000. A new species of Nehvizdya (Ginkgoales) from the Lower Cretaceous of the Iberian Ranges (Spain). Review of Palaeobotany and Palynology 111, 49-70.

Guo, S., 1990. A brief review on megafloral sucessions and climatic changes of the Cretaceous and early Tertiary in China. In: Knobloch, E., Kvaček, Z. (Eds.) Proceedings of the symposium "Paleofloristic and paleoclimatic changes in the Cretaceous and Tertiary". Prague, p. 23-38.

Harris, T.M., Millington, W., Miller, J., 1974. The Yorkshire Jurassic Flora IV. Ginkgoales and Czekanowskiales. Trustees of the British Museum (Natural History), London.

Herman, A.B., Spicer, R.A., 2010. Mid-Cretaceous floras and climate of the Russian high Arctic (Novosibirsk Islands, Northern Yakutiya). Palaeogeography, Palaeoclimatology, Palaeoecology 295, 409-422.

Hluštík, A., 1977. The nature of Podozamites obtusus Velenovský. Acta Musei Nationalis Pragae B 30, 173-185.

Hluštík, A., 1986. Eretmophyllous Ginkgoales from the Cenomanian. Acta Musei Nationalis Pragae B 42, 99-120.

Knobloch, E., Mai, D.H., 1999. Evolution of Middle and Upper Cretaceous floras in Central and Western Europe. Jahrbuch der geologischen Bundesanstalt 134, 257-270.

Krassilov, V.A., 1967. Early Cretaceous flora of South Primorye and its stratigraphic significance. Akademiia Nauk SSSR, Moscow (in Russian).

Krassilov, V.A., 1972. Mesozoic Flora from the Bureja River (Ginkgoales and Czekanowskiales). Akademiia Nauk SSSR, Moscow (in Russian).

Kvaček, J., 1999. New data and revision of three gymnosperms of the Cenomanian of Bohemia-Sagenopteris variabilis (Velenovský) Velenovský Mesenea bohemica (Corda) comb. n. and Eretmophyllum obtusum (Velenovský) comb. n. Acta Musei Nationalis Pragae B 55, 15-24.

Lydon, S.J., Watson, J., Harrison, N.A., 2003. The lectotype of Sphenobaiera ikorfatensis (Seward) Florin, a ginkgophyte from the Lower Cretaceous of western Greenland. Palaeontology 46, 413-421.

MacLeod, S.E., Hills, L.V., 1991. Late Jurassic to Early Cretaceous (Tithonian to preAlbian) plant macrofossils, northern Bowser Basin British Columbia, Canada. Review of Palaeobotany and Palynology 70, 9-45.

Nguyen Tu, T.T., Bocherens, H., Mariotti, A., Baudin, F., Pons, D., Broutin, J., Derenne, S., Largeau, C., 1999. Ecological distribution of Cenomanian terrestrial plants based on ${ }^{13} \mathrm{C} /{ }^{12} \mathrm{C}$ ratios. Palaeogeography, Palaeoclimatology, Palaeoecology 145, 79-93.

Pardo, G., Villena, J., 1979. Características sedimentológicas y paleogeográficas de la Formación Escucha. Cuadernos de Geología Ibérica 5, 407-418.

Pardo, G., Ardevol, L., Villena, J., 1991. Las Formaciones Escucha y Utrillas en la hoja $1: 200.000, N^{\circ} 40$ (Daroca): estudio sedimentológico y síntesis paleogeográficas. Informe complementario a la Memoria del Mapa Geológico de España, E 1:200.000, hoja n 40 (Daroca). ITGE, Madrid.

Pons, D., Boureau, E., Broutin, J., 1976. Nouvelles études paléobotaniques des environs d'Angers I. Eretmophyllum andegavense nov. sp., Ginkgoale fossile du Cénomanien. Comptes rendus du $97^{\mathrm{e}}$ congrès national des Sociétés savantes, Nantes 1972, 4, pp. 357-369.

Pons, D., Lauverjat, J., Broutin, J., 1980. Paléoclimatologie comparée de deux gisements du Crétacé supérieur d'Europe occidentale. Mémoires de la société géologique de France N.S, 139, pp. 151-158.

Pott, C., Van der Burgh, J., Van Konijnenburg-van Cittert, J.H.A., 2016. New ginkgophytes from the Upper Triassic - Lower Cretaceous of Spitsbergen and Edgeøya (Svalbard Arctic Norway): the history of Ginkgoales on Svalbard. International Journal of Plant Sciences 177, 175-197.

Querol, X., 1990. Distribución de la materia mineral y azufre en los carbones de la Formación Escucha. Relación con los factores geológicos, sedimentológicos y diagenéticos. , Ph.D. Thesis, Universitat de Barcelona. (Unpubl.).

Querol, X., Salas, R., Pardo, G., Ardevol, L., 1992. Albian coal-bearing deposits of the iberian range in northeastern Spain. In: McCabe, P., Parrish, J. (Eds.), The controls on distribution and quality of cretaceous coals, 267, Geological Society of America Special Paper, pp. 193-208.

Salas, R., Guimerá, J., Mas, R., Martín-Closas, C., Meléndez, A., Alonso, A., 2001. Evolution of the Mesozoic Central Iberian Rift System and its Cainozoic inversion (Iberian Chain). In: Ziegler, P.A., Cavazza, W., Robertson, A.F.H., CrasquinSoleau, S. (Eds.), Peri-Tethyan Rift/Wrench Basins and Passive Margins. Mémoires du Musée National d'Histoire Naturelle, 186, pp. 145-185.

Samylina, V.A., 1956. Epidermal structure of leaves within the Genus Sphenobaiera. Doklady Akademiia Nauk SSSR 106, 537-539.

Samylina, V.A., 1963. The Mesozoic flora of the lower course of the Aldan River. Palaeobotanika 4, 58-139.

Samylina, V.A., 1967. The Mesozoic flora of the area to the west of the Kolyma River (the Zyrianka Coal-basin) II. Paleobotanica V, 135-175 (in Russian, with English summary)

Sender, L.M., 2012. Albian (uppermost Early Cretaceous) paleobotany (macroremains) and palaeoenvironments from the north of Teruel province (Spain). Ph.D. Thesis, University of Zaragoza. (Unpubl.).

Sender, L.M., Diez, J.B., Ferrer, J., Pons, D., Rubio, C., 2005. Preliminary data on a new Albian flora from the Valle del Rio Martin, Teruel Spain. Cretaceous Research 26 898-905.

Sender, L.M., Diez, J.B., Pons, D., Villanueva-Amadoz, U., Ferrer, J., 2008. Middle Albian gymnosperms from the Río Martín Valley (Teruel Spain). Comptes Rendus Palevol 7, 37-49. 
Sender, L.M., Doyle, J.A., Villanueva-Amadoz, U., Pons, D., Diez, J.B., Ferrer, J., 2016. First records of the angiosperm genus Sapindopsis Fontaine (Platanaceae) in western Eurasia from middle to latest Albian deposits of Spain. Review of Palaeobotany and Palynology 230, 10-21.

Seward, A.C., 1926. The Cretaceous Plant-bearing rocks of Western Greenland. Philosophical Transactions of the Royal Society of London B, 215, pp. 57-175.

Spicer, R.A., Herman, A.B., 2001. The Albian-Cenomanian flora of the Kukpowruk River, western North Slope, Alaska: stratigraphy, palaeofloristics, and plant communities. Cretaceous Research 22,1-40.

Sun, G., Lydon, S.J., Watson, J., 2003. Sphenobaiera ikorfatensis (Seward) Florin from the Lower Cretaceous of Huolinhe, eastern Inner Mongolia, China. Palaeontology 46, 423-430.
Vakhrameyeev, V.A., 1991. Jurassic and Cretaceous floras and climates of the earth. Cambridge University Press, Cambridge.

Villanueva-Amadoz, U., 2009. Nuevas aportaciones palinoestratigráficas para el intervalo Albiense-Cenomaniense en el Sector NE de la Península Ibérica. Implicaciones paleogeográficas y paleoclimáticas. , Ph.D. Thesis, University of Zaragoza. (Unpubl.)

Villanueva-Amadoz, U., Diez, J.B., Ferrer, J., Pons, D., Sender, L.M., 2010. Angiosperm pollen grains of San Just site (Escucha Formation) from the Albian of the Iberian Range (north-eastern Spain). Review of Palaeobotany and Palynology 162, 362 381.

Zhou, Z.Y., 2009. An overview of fossil Ginkgoales. Palaeoworld 18, 1-22. 